\title{
The Eucharist and Freedom: Recalling the Impact of the Magisterium of Pope John Paul II at the International Eucharistic Congress at Wrocław (1997)
}

\section{Abstract}

The article treats the lasting relevance of the Magisterium of Blessed John Paul II during the Forty-sixth International Eucharistic Congress, held in the important Polish city of Wrocław, in 1997. The article highlights the originality of the theme of the Congress, namely, the important relationship binding together the celebration/adoration of the Eucharist and human freedom, while making appropriate cross-references to the same topic in other documents by the Slav Pope. Eucharistic orthopraxis is not only related to disinterested service in favour of one's neighbour in commendable actions of diakonia, but also to the quest for freedom in the context of the respect of civil and social liberties and the exercise of religious freedom.

\section{Keywords}

John Paul II, Wrocław, International Eucharistic Congresses, Eucharist, freedom, school of freedom, Christian social teaching.

Fifteen years have passed since the eventful celebration of the Forty-sixth International Eucharistic Congress, held in the Polish city of Wroclaw in 1997. This article seeks to evoke the memories and the message of that important ecclesial event for the Universal Church. The important message by Pope John Paul II at that Congress continues to enjoy special relevance on account of the particular orthopractical dimension developed in relationship to the sacrament of the Eucharist. Wrocław, the principal city of Lower Silesia and the fourth largest in Poland, has had a long, turbulent and chequered history. It passed to and fro, 


\section{The Person and the Challenges \\ 194

from country to country, and consequently bears witness to Polish, Czech and Prussian-German influences ${ }^{1}$. This striking feature has left a visible mark on the city and its culture, in spite of the fact that it is estimated that seventy-per-cent of Wrocław was destroyed during the Second World War. Wrocław has indeed proved to be a confluence of cultures and religions, a meeting place of religions and traditions ${ }^{2}$.

The theme of the Forty-sixth International Eucharistic Congress, held at Wrocław from the $25^{\text {th }}$ May to the $1^{\text {st }}$ June 1997, was The Eucharist and Freedom. Christ set us free, so that we should remain free (Gal 5,1). It is indeed significant to highlight the fact that this was the first Eucharistic Congress to be held in a former Warsaw Pact country after the fall - a few years earlier - of Communism in Central and Eastern Europe. In fact, when he met the national delegations, from all over the world, at the Congress, Pope John Paul II highlighted its highly symbolic and pregnant significance: "Allow me to stress yet another very important aspect, and that is the place in which the Congress is taking place. It is in Poland, one of the countries of Central Eastern Europe which, together with other countries of this region, has recently regained freedom and sovereignty after years of oppression by the totalitarian Communist system. Also significant is the slogan of the Congress: For freedom Christ has set us free (Gal 5,1). Here, in this part of Europe, the word 'freedom' takes on a special meaning. We know the taste of slavery, war and injustice. So do those countries which lived, like us, the tragic experiences of the lack of personal and social freedom. Today we rejoice at freedom regained, but it is impossible merely to possess and enjoy freedom. It must be continually regained through the truth. Freedom entails the mature responsibility of human consciences, which is the result of this truth. It can be used correctly or badly, in the service of the true good or of a false, fictitious good. Christ present in the Eucharist teaches us what true freedom is and how to use it.

${ }^{1}$ The change in the name of the city over the ages bears witness to the changing borders which have waxed and waned in that part of Central Europe: Wrotizla, Wretslaw, Presslaw, Bresslau, Breslau, Wrocław.

${ }^{2}$ Wrocław has been designated as the European Capital of Culture for the year 2016. A section of the mission statement (regarding this event) which outlines the aspirations of this Polish city deserves to be mentioned in the context of this article: "We dream about the culture that will connect nations instead of separating them. We dream about the future with no one deprived of an opportunity to participate in cultural life and with all Europeans participating in culture, regardless of their religion, gender, age or financial situation. Wrocław will become the place of dialogue about the special role of culture in creating Europe without barriers". http://www.wro2016.pl/en/ why-wroclaw/ (15 V 2012). 
"Today there is a need for a great return to the Eucharist. Only the Eucharist can reveal to man the fullness of God's infinite love and thus answer his desire for love. Only the Eucharist can set on course his yearnings for freedom, and thus show him the new dimension of human existence"3. This article will study the relationship between the Eucharist and freedom in the preparatory document of the Congress, and will then focus on excerpts from the magisterial speeches made by the Polish Pope during the concluding phase of the international gathering. For the first time in the history of International Eucharistic Congresses, the chosen theme focused upon a stimulating dimension of the theology of the Eucharist in the life and the mission of the Church. In fact, the particularity of this landmark ecclesial gathering lies in "presenting and celebrating the mystery of the Eucharist in the light of a concept of far-reaching anthropological, social and salvific significance: freedom. This word 'freedom' expresses the great quest of humanity, the desire of all people. Freedom is an expression of that spark of truth and life with which humanity was created in the image and likeness of God"4.

In his earlier Magisterium, Pope John Paul II had already treated the theme of human freedom. He described it as a gift of God, "one to be received like a seed and to be cultivated responsibly. It is an essential part of that creaturely image which is the basis of the dignity of the person. Within that freedom there is an echo of the primordial vocation whereby the Creator calls man to the true Good, and even more, through Christ's revelation, to become his friend and to share his own divine life"s.

Moreover, in one of the early speeches of his pontificate, John Paul II had affirmed that liberation, one of the fundamental biblical themes, is profoundly present in the saving mission of Jesus ${ }^{6}$. Furthermore, in the Encyclical Letter Sollicitudo Rei Socialis, in which he illustrates the confluence between the social teaching of the Church and the Eucharist, he praised the human quest for freedom from bondage: "the aspiration to freedom from all forms of slavery affecting the

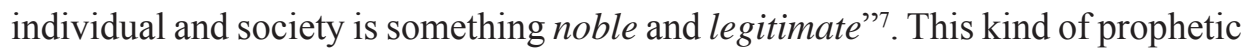

\footnotetext{
${ }^{3}$ John Paul II, Address to Delegations to the International Eucharistic Congress, Wrocław, Poland (1 June 1997), 4.

${ }^{4}$ http://www.ewtn.com/library/curia/euchfree/htm (13 V 2012).

${ }^{5}$ John Paul II, Encyclical Letter regarding certain Fundamental Questions of the Moral Teaching of the Church Veritatis Splendor (6 August 1993), 86.

${ }^{6}$ See John Paul II, Address during Wednesday General Audience (21 February 1979), in Insegnamenti di Giovanni Paolo II, II/1. Gennaio-giugno 1979, Città del Vaticano 1979, Libreria Editrice Vaticana, p. 428-431.

${ }^{7}$ John Paul II, Encyclical Letter for the 20th Anniversary of "Populorum Progressio" Sollicitudo Rei Socialis (30 December 1987), 46.
} 
action is realised by an imitation of Christ who acted consistently as diakonos kai doulos. Throughout his entire mission, he showed that "freedom is acquired in love, that is the gift of self", and that the perfect practice of freedom entails "the gift of self in service to God and one's brethren"s.

\section{The Preparatory Document of the Congress}

In its introduction, the preparatory document of the Forty-sixth International Eucharistic Congress affirms that the theme which had been chosen was being studied for the first time. The relationship between the Eucharist and human freedom - a stimulating field for reflection - had been judged to be so pertinent because of the city of Wrocław and the geographical region chosen by the Holy See to host the congress. Following the widespread socio-political momentous events of 1989 in Central and Eastern Europe, several peoples and nations reacquired civil liberties which had long been trampled underfoot by totalitarian regimes. By celebrating an International Eucharistic Congress in Wrocław, the organising committee of the Holy See also intended to provide a guiding light to the peoples and nations which had undergone traumatic experiences on account of the negation of personal and social rights for several decades ${ }^{9}$. While centring their thoughts and prayers on the mystery of the Eucharist, Christians both from these nations as well as from all over the world, reflected on how this sacrament is

${ }^{8}$ John Paul II, Veritatis Splendor, 87.

${ }^{9}$ See Pontifical Committee for International Eucharistic Congresses (hereafter PCIEC), The Eucharist and Freedom (16 May 1995), 5, "Notitiae" 32 (1996), p. 722-755: "Freedom has been trampled down by totalitarian systems in the countries of the East: both by the brutality of Stalinist oppression, and by the tyranny of Nazism. The power of a spirit of independence has, nonetheless, become apparent even when in public life freedom has been severely restricted or completely eliminated. The totalitarian systems did not endeavour to form human persons from within, they imposed external pressure. According to the ideology they proclaimed, industrialized society, which came about as a result of scientific and technological achievements, could not become the fruit of free decisions involving the participation of all free people. Freedom became untrustworthy.At the same time, these systems showed themselves to be powerless when confronted with the inner freedom of human persons. Concentration camps, gulags, prisons and political trials brought about the inhuman destruction of millions of human beings. But they also occasioned untold triumphs of the human spirit. Human life took on a deeper significance in pardon, in effective love for one's neighbour, to the point of offering one's own life for the good of the enemy and for a better world. These were the triumphs of men and women whose lives were never disfigured by betrayal, collaboration with the forces of evil or compromise with the powerful". 
instrumental in enhancing the experience of freedom, both on a personal as well as on a social dimension ${ }^{10}$.

The preparatory document enunciates that the aim of the Forty-sixth International Eucharistic Congress was to present and celebrate the mystery of the Eucharist as an agent of human freedom. This latter reality has multifaceted anthropological, social and salvific implications, and is yearned for both by individual believers as well as by nations. Freedom is a divine gift to humanity in creation, and more so, in redemption ${ }^{11}$. Thus, without in any way diminishing the significance of a Eucharistic Congress treating the theme of social liberties, one is not to overlook the primacy of the inner freedom of the individual. Writing more than fifteen years prior to the fall of the Berlin Wall, David Power affirms that "the freedom which is worth seeking is not in the long run freedom from political oppression, freedom from economic slavery, freedom from the constraints of poverty, freedom of speech or freedom of gathering. It is the inner freedom which allows a man to be master of his own destiny. [...] All the other freedoms are relevant and important in as much as they create the environment in which this is possible" 12 .

Another relevant consideration to be made is that the theme of the Congress has to be contextualised within the spiritual preparation for the Great Jubilee of the Year 2000. The Preparatory Document affirms: "A strong summons to Christian freedom springs from its happy coincidence with the immediate preparation for the Great Jubilee of the Year 2000. In the tradition of the people of Israel, a Jubilee Year was indeed a joyful and community celebration of the freedom and liberation offered to all by God. Christ himself, consecrated by the Spirit and sent by the Father, came to put into effect the great Jubilee of redemption"13. The Jewish Jubilee year which was celebrated every fifty years by the chosen People was an opportunity for social readjustment through the reacquisition of freedom and the pardoning of depths. Consequently, the Jubilee was a joyful experience because of the sense of liberation which pervaded the poorer and underprivileged classes of Jewish society. The concept of freedom has been retained, albeit on a spiritual level, in the Christian celebration of the Holy Years, ever since their inception in 1300 by Pope Boniface VIII.

Faced with the difficulties encountered in understanding the authentic meaning of freedom, the preparatory document proposes a meditation of the crucified and

\footnotetext{
${ }^{10}$ See PCIEC, The Eucharist and Freedom, 1.

${ }^{11}$ See PCIEC, The Eucharist and Freedom, 2.

${ }^{12}$ D. Power, The Song of the Lord in an Alien Land, "Concilium" 92 (1974), p. 90.

${ }^{13}$ PCIEC, The Eucharist and Freedom, 3.
} 
risen Christ, the perfect example of human freedom unto death. The text quotes John Paul II's Encyclical Letter Veritatis Splendor: "The Crucified Christ reveals the authentic meaning of freedom; he lives it fully in the total gift of himself and calls his disciples to share in his freedom"14. Thus, the contemplation of Jesus Christ in the paschal mystery constitutes the path leading towards a holistic understanding of freedom, namely, the self-offering by Christians as they serve God and their neighbour. In fact, the same encyclical by the Polish Pope affirms that "communion with the crucified and risen Lord is the never-ending source from which the Church draws unceasingly in order to live in freedom, to give of herself and to serve"15. The self-offering of Christ and its direct relationship to liberation and to service had been referred to by Pope John Paul II in the Encyclical Sollicitudo Rei Socialis: "the freedom with which Christ has set us free (see Gal 5,1) encourages us to become the servants of all. Thus, the process of development and liberation takes concrete shape in the exercise of solidarity, $[\ldots]$ in the love and service of neighbour" ${ }^{\prime \prime}$.

The preparatory document also expounds the inextricable relationship which binds together the celebration of the Eucharist and the authentic freedom of the children of God (see Rom 8,21). Christian witness is brought into focus when the text formulates the importance of "being nourished by the word of the Gospel and the Eucharistic bread, by entering into communion with Christ, by adoring the Father in spirit and truth, and by showing love for our brothers and sisters even to the point of giving up our lives for them. We should also remember that in this $\left[20^{\text {th }}\right]$ century, as during the first ages of the Church, the Eucharist has been the Bread of Freedom, the viaticum for courage and martyrdom" 17 .

Indeed, the concentration camps, the gulag and all the other sites of oppression and extermination of the last hundred years have become the arenas where modern-day martyrs have shed their blood. In the Encyclical Letter Veritatis Splendor to which the preparatory document often refers, John Paul II speaks about the perennial relevance of martyrdom as one of the significant features of the followers of Christ and as an outstanding sign of the holiness of the Church. The document also observes that the terminology of the Eucharistic anaphoras articulates the freedom with which Christ offered himself in love to the Father for humanity ${ }^{18}$. The document also affirms that the Eucharist expresses "the mystery

\footnotetext{
${ }^{14}$ John Paul II, Veritatis Splendor, 85. This text is quoted in PCIEC, The Eucharist and Freedom, 8.

${ }^{15}$ John Paul II, Veritatis Splendor, 87; see PCIEC, The Eucharist and Freedom, 8.

${ }^{16}$ John Paul II, Sollicitudo Rei Socialis, 46.

${ }^{17}$ PCIEC, The Eucharist and Freedom, 9.

${ }^{18}$ See ibid., 11.
} 
of Christ's freedom, the gift of liberation; it means love to the end, for only love can liberate" 19 .

The concept of human freedom in relation to the Eucharist can be traced back to the Jewish Passover, the annual commemoration of the liberation of the chosen People from Egyptian bondage. For Israel, the paschal meal entailed the re-living of their deliverance from slavery. Moreover, during this meal those present often reclined, hence adopting the posture of a free person at table. In his supreme and total self-offering, Jesus accomplished the redemption of humanity and its liberation from sin: "in the sacrifice of the New Covenant, he expresses the fullness of our liberation and our salvation with the inner gift of the Spirit, and he summons us to the eternal Passover in his Kingdom"20. This personal transformation is achieved by the Holy Spirit who instils the same attitudes as those of the self-forgetful Christ in the hearts of Christians.

A pivotal theme in the preparatory document is the liberating power of charity. An authentic spirit of communion within the community strengthens the bonds of love among the individual members, and stimulates them to offer themselves in service to each other. Such a lifestyle is an eloquent expression of the fact that "all barriers of selfishness have been broken down by the freedom with which Christ has set us free" ${ }^{21}$. Irenaeus of Lyons was thrilled when he reflected upon the freedom achieved by Christ in the communities assembled in his name, and was so convinced of this that he called the first disciples "preachers of truth and apostles of freedom"22. Moreover, this second-century Church Father reflects upon the Eucharist from the point of view of freedom by observing that since it is a gift from the Lord, it is also an offering made by a community of believers that rejoices in its liberty ${ }^{23}$.

The earliest local Churches were aware of the liberating power of the sacrament which thus revolutionised both the lives of individuals and communities, as well as the society to which they belonged: "Even in the midst of persecutions, the first Christian communities understood and bore witness to the fact that the Eucharistic celebration was the source of a great impetus to mutual charity. This charity was able to make brothers and sisters of them all, forming them into a new people who

\footnotetext{
${ }^{19}$ Ibid., 12.

${ }^{20}$ Ibid., 13.

${ }^{21}$ Ibid., 15.

${ }^{22}$ Irenaeus of Lyons, Adversus Haereses, 3,15,3, as quoted in PCIEC, The Eucharist and Freedom, 15.

${ }^{23}$ See Irenaeus of Lyons, Adversus Haereses, 4,18,1-2, as quoted in PCIEC, The Eucharist and Freedom, 15.
} 
were educated to bear witness courageously even to the point of martyrdom. They became capable of bringing about the renewal of society through their charity and a fresh sense of solidarity that sprang from the Eucharistic celebration and became expressed in the sharing of their goods and contribution towards those in need"24.

The document states that it is only the truth proclaimed by Christ which brings about authentic freedom. After having described the effects of sin and egoism, the text then presents one of the positive dimensions of freedom, namely, self-offering. This reaches its climax in service and witness because sacramental grace permeates the actions of those who put the Eucharist at the centre of their existence ${ }^{25}$. Another aspect of the relationship between the Eucharist and human freedom is conversion, an essential dimension of the Christian message. The preparatory document distinguishes between a negative and a positive understanding of metanoia. The former concerns liberation from whatever may threaten the human condition, and thus entails the struggle against the alienation caused by sin. On the other hand, the latter point of view entails conversion vis-à-vis the realisation of the positive qualities of the human person and their subsequent development ${ }^{26}$. The path of holiness and perfection is thus considered as an ongoing process of growth in human freedom. Participating in the Eucharistic banquet strengthens Christians as they journey along this route. This dimension is highlighted by the document through its reference to Pope John Paul II's Encyclical Letter Veritatis Splendor: "By sharing in the sacrifice of the Cross [through the sacraments, especially in the Eucharist], the Christian partakes of Christ's self-giving love and is equipped to live this same charity in all his thoughts and deeds. In the moral life the Christian's royal service is also made evident and effective: with the help of grace, the more one obeys the new law of the Holy Spirit, the more one grows in the freedom to which he or she is called by the service of truth, charity and justice" 27 .

The theme of the Forty-sixth International Eucharistic Congress focuses upon the response in faith and love made by individual Christians in offering themselves in union with Christ. The members of the Church are invited to grow in the awareness that this self-oblation renders them collaborators with God

\footnotetext{
${ }^{24}$ PCIEC, The Eucharist and Freedom, 15.

${ }^{25}$ See ibid., 17.

${ }^{26}$ See ibid., 18.

${ }^{27}$ John Paul II, Veritatis Splendor, 107. This text is quoted in PCIEC, The Eucharist and
} Freedom, 19. 
in the diffusion of authentic freedom which illumines the lives of individual believers, families, communities and peoples ${ }^{28}$. Whenever they celebrate the Eucharist, Christians are requested to offer themselves as an everlasting gift to God. This attitude opens their hearts and their minds to experience the freedom of the children of God (see Rom 8,21), and thus to promote true human liberation and "the power of truth, goodness, beauty and justice" in the society where they live ${ }^{29}$. In the conclusion of the document, the transforming effect of Eucharistic grace upon social life is succinctly presented: "May the grace of the Eucharist, which is proclaimed, celebrated, communicated and adored, contribute towards breaking the circle of oppression, hatred and selfishness. May it promote a great movement of charity also in the social sphere through sincere commitment even to the point of giving up one's life for others. Through the culture of communion and unity, may it open up a new and wholly different horizon for the countries of the East that have only emerged from a long period of oppression, and for all nations throughout the world. The disciples of Jesus will become in this way the seed of a new society where, in mutual solidarity, each one will gladly bear another's burdens and those who are interiorly free and reconciled will experience happiness and social peace" ${ }^{\prime 3}$.

\section{The Eucharist and Freedom in the Speeches by Pope John Paul II in the Conclusion of the Forty-sixth International Eucharistic Congress}

Having presented an outline of the preparatory document of the Eucharistic Congress held at Wrocław in 1997, it is appropriate and timely to highlight the references made by Pope John Paul II with regard to the general theme of the ecclesial gathering. The homily delivered by the great Polish Pope at the closing Mass of the Congress is particularly eminent since he binds together the Eucharist and the challenge of world hunger, within the context of the call to freedom in Christ.

Depicting the Eucharist as "the food and drink that transform man's life" 31 , the Pope affirmed that the celebration of the Congress offered yet another opportunity to make a plea on behalf of those suffering from hunger. John Paul II exhorted the

${ }^{28}$ See PCIEC, The Eucharist and Freedom, 23.

${ }^{29}$ Ibid., 30.

${ }^{30}$ Ibid., 31.

${ }^{31}$ John Paul II, Homily at the Closing Mass of the International Eucharistic Congress, Wrocław, Poland (1 June 1997), 3. 
congregation to remain aware of the Christian duty of sharing the essentials of life with the needy. Selfless sharing is one of the lessons imparted by the sacrament of the Eucharist ${ }^{32}$. In an important section of the sermon, the Pope dwelt upon the impact of the Eucharist in the re-ordering of human freedom. He declared: "The Congress exhorts us to look at human freedom from a Eucharistic perspective. In the Congress hymn we sing: 'You have left us the gift of the Eucharist to re-order inner freedom'. This is a most essential affirmation. We speak here of the 'order of freedom'. Yes, true freedom demands order. But what kind of order are we talking about here? We are talking first of all about the moral order, order in the sphere of values, the order of truth and goodness. [...] The Church never ceases to be in the world the proclaimer of the gospel of freedom! This is her mission. 'For freedom Christ has set us free' ( Gal 5,1 $)^{33}$.

Towards his conclusion, Pope John Paul II explained how sacramental grace in the Eucharist contributes to the acquisition of human freedom. He affirmed that the personal self-offering by Christians is an actualisation of the gift of freedom. When individual believers are able to be totally available, they would have reached a degree of interior freedom which leads them to act altruistically, thus becoming men and women for others. This recaptures the particularly evocative words used by John Paul II in the document, published a year earlier, to commemorate the fourth centenary of the Union of Brest: "remembrance of the martyrs cannot be erased from the memory of the Church or of humanity" ${ }^{\prime 34}$, because their fortitude transmits a powerful manifestation of intense love and unflinching fidelity to the Lord and to the community. Therefore, it is 'the highest point of the life of grace, [...] the truest communion possible with Christ who shed his Blood"35.

Under the action of the Holy Spirit, those who partake of the Eucharist become more alert of their duty to open their hearts to those hungering for bread, justice, love and freedom. The Polish Pope seized this catechetical opportunity at the Wrocław Congress to assert, in highly evocative terms, that the Eucharist is $a$ school of freedom, training Christians in the creation of a new order of freedom. Eating and drinking the sacramental Body and Blood of the glorified Christ instils in the baptised a pro-existential attitude marked by a disinterested self-offering to others. The Pope affirmed: "Modelled on the Eucharist, what does this order

\footnotetext{
${ }^{32}$ See ibid., 4.

${ }^{33}$ Ibid., 5.

${ }^{34}$ John Paul II, Apostolic Letter for the Fourth Centenary of the Union of Brest Nablizaet'sja den' (12 November 1995), 8.

35 John Paul II, Encyclical Letter on Commitment to Ecumenism Ut Unum Sint (25 May 1995), 84.
} 
of freedom consist in? In the Eucharist, Christ is present as the one who gives himself to man, as the one who serves man: 'having loved his own [...] he loved them to the end' (Jn 13,1). True freedom is measured by readiness to serve and by the gift of self. Only when it is understood in this way is freedom truly creative, only then does it build up our humanity and create interhuman bonds" ${ }^{\prime 36}$.

This papal sermon has been described as one of the key Eucharistic texts of the long pontificate of Blessed John Paul II, particularly because of that inextricable bond he strives to explain between the sacrament on one hand, and the interior freedom predisposing individuals to service on the other ${ }^{37}$. This recaptures the nexus he had made between the Eucharistic change and the union of the faithful with Christ in his Encyclical Sollicitudo Rei Socialis: "The goods of this world and the work of our hands - the bread and the wine - serve for the coming of the definitive Kingdom, since the Lord, through his Spirit, takes them up into himself in order to offer himself to the Father and to offer us with himself in the renewal of his one Sacrifice" 38 .

Moreover, in the message preceding the Sunday Angelus at the end of the Mass in Wrocław, Pope John Paul II reiterated his emphasis on the centrality of the Lord's Table to the daily lives of Christians. He exhorted those present to find strength in the Eucharist, especially while struggling to serve others. Christians are constantly reminded that the celebration of the sacraments is not an isolated action, but lies at the very heart of their existence, as they commit themselves to bear fruit by witnessing to the kerygma of Jesus. In the Angelus address, the Pope prayed: "May the mystery of the Eucharist penetrate your whole lives. From the Eucharist may your love of God and neighbour draw strength, may your faith be enkindled and your hope renewed" 39 .

In another homily, during the same pastoral visit to Poland, fifteen years ago, John Paul II reflected upon the relationship of the Eucharist to social life. In fact, at Legnica he described the Eucharist as "the source of social love"

\footnotetext{
${ }^{36}$ John Paul II, Homily at the Closing Mass of the International Eucharistic Congress, Wrocław, Poland (1 June 1997), 5.

${ }^{37}$ This was admirably and incisively affirmed in an editorial published in the Vatican semiofficial daily newspaper, L'Osservatore Romano. The editor penned this striking evaluation: " $\mathrm{Di}$ validità universale è stata l'omelia di Giovanni Paolo II: una delle più alte del suo Pontificato, dalla robustezza di una enciclica e dall'intelligenza dell'oggi della storia. [...] Eucaristia, fame, libertà: una trilogia che ha scosso tutti e che riguarda tutti. Una trilogia che impone un esame di coscienza. Una trilogia che propone indicazioni concrete. Dall'eucaristia sgorgano l'ordine della libertà e la solidarietà interumana" (M. Agnes, Editorial, "L’Osservatore Romano" (2-3 June 1997), 1.

${ }^{38}$ John Paul II, Sollicitudo Rei Socialis, 48.

${ }^{39}$ John Paul II, Address at the Sunday Angelus, Wrocław, Poland (1 June 1997), 3.

${ }^{40}$ John Paul II, Homily at Mass, Legnica, Poland (2 June 1997), 6.
} 
that the sharing at the sacred synaxis calls for a commitment in favour of those lacking their fair share of daily bread. He declared that "as we approach the Eucharistic table to be fed with [Christ's] Body, we cannot remain indifferent to those who lack daily bread. We need to talk about them, but we must also meet their needs" $"$.

When he met the Eucharistic Congress delegations, Pope John Paul II reiterated that the spiritual wealth intrinsic to the Altar of the Lord energises Christians in the exercise of their manifold responsibilities. During this encounter, he insisted that Jesus Christ imparts the full significance of authentic freedom. Referring to the dramatic political changes of 1989, he underlined the profound link between the Eucharist and freedom: "Christ present in the Eucharist teaches us what true freedom is and how to use it. [...] Only the Eucharist can reveal to man the fullness of God's infinite love and thus answer his desire for love. Only the Eucharist can set on course his yearnings for freedom, and thus show him the new dimension of human existence. For when we discover that we have been called to make a free gift of ourselves to God and neighbour, our freedom is permeated by the splendour of truth which makes our love radiant" ${ }^{\prime 42}$.

These words are a clear reminder of the determination expressed by John Paul II in the Encyclical Sollicitudo Rei Socialis, in which he forges together the celebration of the Eucharist and the promotion of justice and co-operation. The Pope declares that participation in the Table of the Lord comprises both a commitment to mission, as well as a call to discern "the profound meaning of our actions in the world in favour of development and peace; and to receive from it [i.e. the Eucharist] the strength to commit ourselves even more generously, following the example of Christ, who in this sacrament lays down his life for his friends" ${ }^{\prime 3}$.

\section{Conclusion}

The International Eucharistic Congress held in the Polish city of Wrocław in 1997 offered new and remarkable insights into the orthopractical dimension of the sacrament of the Eucharist. Blessed John Paul II took the timely opportunity to highlight the important relationship between the Eucharist and human freedom.

\footnotetext{
${ }^{41}$ Ibid., 3.

${ }^{42}$ John Paul II, Address to Delegations to the International Eucharistic Congress, Wrocław, Poland (1 June 1997), 4.

${ }^{43}$ John Paul II, Sollicitudo Rei Socialis, 48.
} 
Following, on one hand, the historic events of 1989 which altered the face of Europe and, on the other hand, proceeding in the context of the preparation for the celebration of the Great Jubilee of the Year 2000, the Magisterium of John Paul II at Wrocław displays, at first glance, a degree of originality, but on deeper reflection, the theme can be traced as far back as the Old Testament foreshadowing of the Eucharist in the Exodus experience of the chosen People of God. The celebration of the liberating love of God in liturgy and life leads to an enhanced awareness of a paschal ethic in the lives of Christians. The lasting relevance of the Fortysixth International Eucharistic Congress lies in the recapitulation of a number of central social themes treated in previous Eucharistic Congresses, as well as the emphasis made in the social encyclicals of the Pope's, particularly Sollicitudo Rei Socialis. This article shows and explains how Eucharistic orthopraxis is not only related to disinterested service in favour of one's neighbour in commendable actions of diakonia, but also to the quest for freedom in the context of the respect of civil and social liberties and the exercise of religious freedom.

Some years after the Wrocław Eucharistic Congress, Pope John Paul dedicated an Encyclical to the Eucharist, Ecclesia de Eucharistia (17 April 2003), as well as an Apostolic Letter at the beginning of the year he dedicated to the Eucharist, Mane nobiscum Domine (7 October 2004). The social dimension of the Eucharist would be further developed, later, in the third and final major section of the Apostolic Exhortation by his successor, Pope Benedict XVI, Sacramentum Caritatis (22 February 2007): The Eucharist - a mystery to be lived. George Weigel, the acclaimed biographer of John Paul II, pens a moving reflection on the last Eucharistic document of the second longest pontificate, Mane nobiscum Domine: "the title was beyond poignant, in that the Gospel story of the two disciples who asked the Risen Christ to 'stay with us' on the road to Emmaus that first Easter did so because 'it is toward evening and the day is now far spent' (Lk $24,29)$ - as it surely was for Karol Wojtyła" ${ }^{\prime 4}$. Perhaps, the final lap of that long Eucharistic journey had been inaugurated during his memorable visit to Wrocław in 1997.

${ }^{44} \mathrm{G}$. Weigel, The End and the Beginning. Pope John Paul II - The Victory of Freedom, the Last Years, the Legacy, New York 2010, Image Books, p. 367. 


\section{Bibliography}

John Paul II, Encyclical Letter for the 20 $0^{\text {th }}$ Anniversary of "Populorum Progressio" Sollicitudo Rei Socialis (30 December 1987); English trans. On Social Concerns, Vatican City 1988, Libreria Editrice Vaticana.

John Paul II, Encyclical Letter regarding certain Fundamental Questions of the Moral Teaching of the Church Veritatis Splendor (6 August 1993); English trans. The Splendour of Truth Shines, Vatican City 1993, Libreria Editrice Vaticana.

Pontifical Committee for International Eucharistic Congresses, The Eucharist and Freedom (16 May 1995), "Notitiae" 32 (1996), p. 722-755.

Power D., The Song of the Lord in an Alien Land, "Concilium" 92 (1974), p. 85-106.

Weigel G., Witness to Hope. The Biography of Pope John Paul II, New York 1999, Cliff Street Books.

Weigel G., The End and the Beginning. Pope John Paul II - The Victory of Freedom, the Last Years, the Legacy, New York 2010, Image Books. 